\title{
Effect of Educational Intervention on Knowledge Regarding HIV/AIDS among Nursing Assistant Students of Shree Birendra Hospital, Nepal
}

\author{
Padma Rai ${ }^{1}$,Anita Adhikari', Manjari Bajracharya ${ }^{1}$
}

${ }^{1}$ Shree Birendra Hospital, Kathmandu, nepal.

\begin{abstract}
Introduction: : HIV/AIDS is a serious health problem all across the world. The modes of HIV transmission are unprotected sex with infected individual, injection or transfusion of HIV infected blood or blood products, donations of infected semen, organ transplants taken from an infected person and sharing of unsterilized injection equipment. The alarmingly increasing rate of prevalence of HIV among the youths due to engagement in high risk behaviors show that there is a desperate need for assessments to be conducted to ascertain the existing knowledge, attitudes and sexual practices of youths. Methods: One group pre and post-test experimental research design was adopted for the study. The pretest study was conducted on 4 December, 2012; followed by post- test study after two weeks. The study group was provided with course on HIV/AIDS between the tests. The study was carried out in 121 students of nursing assistants of Shree Birendra Hospital. Results: The findings show that the level of knowledge after educational intervention increases significantly. Conclusion: Educational intervention is likely to be significant in increasing awareness about HIV/AIDS.
\end{abstract}

Keywords: HIV/AIDS; knowledge; educational intervention.

\section{INTRODUCTION}

The worldwide spread of Human Immunodeficiency Virus (HIV) infection and Acquired Immuno Deficiency Syndrome (AIDS) is internationally recognized health problem of extraordinary scope and unprecedented urgency. Since it was first diagnosed in 1980s, the struggle against HIV continues. Almost 34.2 million people in the world have HIV, of them over 12.2 million are women. More than 8 million people have access to antiretroviral therapy ${ }^{1}$.

Regarding knowledge about the disease, Diclement $^{2}$ argues that there is a poor correlation between knowledge about HIV/ MJSBH Vol 15 Issue 1 Jan- Jun 2016
AIDS and its transmission; and sexual behavior. Various studies show that people practice unsafe sex despite their knowledge of HIV/AIDS. Prevention programs of HIV/AIDS include communication targeted at behavioral change of most at risk populations (MARPs) like female sex workers (FSW) and their clients, men having sex with men (MSM) and at risk population like prison security services, youth, adolescent and security service personnels (Army and Police) $)^{3}$.

Correspondence: Padma Rai, Shree

Birendra Hospital, Chaunni, Kathmandu.

Email: padmarai10@yahoo.com 
This study was carried out to find out the effectiveness of educational intervention on level of knowledge of HIV/AIDS on nursing assistant students of our institute.

\section{METHODS}

The design of the study was pre-experimental one group pre-test and post- test design (Figure 1). Census method was used for the study. Participants enrolled in courses being conducted by medical training department of Shree Birendra Hospital (SBH) were included. Altogether 121 nursing assistant students were enrolled in the study.

A self-administered structured questionnaire was developed as an instrument to measure the effectiveness of educational intervention on knowledge regarding HIV/AIDS. Respondent's knowledge about HIV/AIDS was considered as a dependent variable and the educational intervention as independent variable. The content validity of the instrument in terms of its adequacy and appropriateness was established by developing instrument based rigorous literature review, and by seeking the opinion of consultant physician working in the field of HIV/AIDS research. The reliability of the instrument was established by pre-testing instrument.

\section{Pretest $\square$ Intervention $\Longrightarrow$ Posttest}

Figure 1: Study design

'Chi Square' test was used to compare the difference in knowledge scores on HIV/AIDS before and after intervention. The difference in gain score of responses between before and after intervention in both groups was computed using 'paired t test'.
Table 1: Distribution of respondents according to socio-demographic Characteristics $(\mathrm{n}=121)$.

\begin{tabular}{|l|c|c|}
\hline Characteristics & Number & Percent \\
\hline Age group & & \\
\hline 20-24years & 43 & 28.1 \\
\hline 25-29 years & 11 & 9.1 \\
\hline 30-34 years & & \\
\hline Sex group & 117 & 96.7 \\
\hline Male & 4 & 9.1 \\
\hline Female & & \\
\hline Marital status & 81 & 66.9 \\
\hline Married & 38 & 31.4 \\
\hline Unmarried & 1 & 0.1 \\
\hline Separated & 1 & 0.1 \\
\hline Widower & & \\
\hline Types of Family & 83 & 61.0 \\
\hline Nuclear & 53 & 39.0 \\
\hline Joint & & \\
\hline RESULS & & \\
\hline
\end{tabular}

\section{RESULTS}

Among the respondents $62.8 \%$ belonged to age group 25-29 years, followed by age group 20 - 24 years $(28.1 \%)$ and age group 30-34 years $(9.1 \%)$ (Table 1$)$. The ethnic background, religion and education of the participations are shown in table 2. The level of knowledge of students on HIV/AIDS before intervention varied significantly and after the educational intervention the level of knowledge of HIV/AIDS was significantly increased (Table 3).

In regards to the contributing factors to increase HIV/ AIDS in Nepal, respondents agreed with the statement, 'low level of condom use contributes in increasing HIV/ 
Table 2:Distribution of Respondent According to ethnic group, religion and education. Characteristics $(n=121)$

\begin{tabular}{|l|c|c|}
\hline \multicolumn{1}{|c|}{ Characteristics } & Number & Percent \\
\hline Ethnic group & & \\
\hline $\begin{array}{l}\text { Chhetri/Brahmin } \\
\text { Hill }\end{array}$ & 93 & 76.9 \\
\hline Janjati & 23 & 19.0 \\
\hline Dalit & 5 & 4.1 \\
\hline Religion & 116 & 95.9 \\
\hline Hindu & 2 & 1.7 \\
\hline Christian & 2 & 1.7 \\
\hline Muslim & 1 & 0.8 \\
\hline Buddhist & & \\
\hline Education & 5 & 4.1 \\
\hline Below SLC & 78 & 64.5 \\
\hline SLC level & 35 & 28.9 \\
\hline Certificate level & 3 & 2.5 \\
\hline Bachelor level & & \\
\hline AIDS', & & \\
\hline
\end{tabular}

AIDS,' which accounted for $96 \%$ of responses prior to intervention. It increased to cent percent after educational intervention package given (Table 4). Responders also chose literacy (99.2\%) and Girls Trafficking (98.3\%) as major causes for spread of HIV/AIDS.

'The high risk group of population most vulnerable to HIV/AIDS' are 'female sex workers,' was chosen by $95 \%$ of respondents prior to intervention. After intervention it was slightly increased and $98.3 \%$ respondents agreed to this (Table 5). In post test $99.2 \%$ respondents opined that 'Migrants Workers' are the population with the high risk of acquiring HIV infection.
In regards to the sources of transmission of HIV/ AIDS, breast feeding and organ / semen donation as possible method of transmission was chosen by $47.1 \%$ to $50.4 \%$ of respondents. It raised to $91.7 \%$ and $94.2 \%$ respectively after educational intervention (Table 6). In pretest $95 \%$ of respondents chose 'use of condom' as possible measure of prevention of HIV/AIDS transmission. It was followed by use sterile equipment such as sterile syringe and needles (91.7 \%) (Tables 7). The respondents' knowledge regarding prevention of mother to child transmission (PMTCT) of HIV was poor before intervention (only about two respondents out of 5 reported that taking anti retroviral therapy (ARV) during pregnancy reduces the transmission). In Post test $90.9 \%$ of respondents had knowledge about role of ARV during pregnancy of HIV infected mother (Tables 8).

Before educational intervention, out of the total respondents $47.9 \%$ respondents had performed the low scoring on knowledge (Table 9) and $52.2 \%$ performed high scoring or knowledge.

After the intervention, $0.8 \%$ respondents had performed low scoring on knowledge and rest $(99.2 \%)$ scored high on knowledge with $\chi^{2}$ ( $p=0.000)$. It shows the level of knowledge of respondents after the educational intervention significantly increased.

\section{DISCUSSION}

Many studies have been done to determine the outcome of educational intervention on knowledge and practice regarding HIV/AIDS and its transmission. Sharma $M$ has concluded that there is significant impact of education on knowledge regarding HIV/AIDS among adults ${ }^{4}$. In our study only $64.5 \%$ respondents were aware that HIV/AIDS is a preventable disease before the educational intervention. It 
Table 3:Knowledge about Meaning of HIV/AID before and after educational intervention.

HIV/AIDS is ....

\begin{tabular}{|l|}
\hline Sexually transmitted disease \\
\hline Blood born disease \\
\hline Preventable disease \\
\hline Fatal disease \\
\hline
\end{tabular}

\section{Before educational intervention After educational intervention}

\begin{tabular}{|c|c|c|c|}
\hline Number & Percent & Number & Percent \\
\hline 119 & 98.3 & 121 & 100.0 \\
\hline 114 & 94.2 & 117 & 96.7 \\
\hline 78 & 64.5 & 100 & 82.6 \\
\hline 7 & 5.8 & 26 & 21.5 \\
\hline
\end{tabular}

Table 4: Contributing Factors in Increasing HIV/AIDS in Nepal before and after intervention.

\begin{tabular}{|c|c|c|c|c|}
\hline \multirow[t]{2}{*}{ Contributing factors } & \multicolumn{2}{|c|}{ Before educational intervention } & \multicolumn{2}{|c|}{ After educational intervention } \\
\hline & Number & Percent & Number & Percent \\
\hline Girl trafficking & 117 & 96.7 & 119 & 98.3 \\
\hline Low level of condom use & 116 & 95.9 & 121 & 100.0 \\
\hline Low literacy level & 115 & 95.0 & 120 & 99.2 \\
\hline Culture /religion & 29 & 24.0 & 92 & 76.0 \\
\hline $\begin{array}{l}\text { Stigma related } \\
\text { discrimination }\end{array}$ & 40 & 33.1 & 95 & 78.5 \\
\hline Unemployment & 100 & 82.6 & 116 & 95.9 \\
\hline \multicolumn{5}{|c|}{$\begin{array}{l}\text { Table 5: Respondents' Knowledge Regarding Most at Risk \& at risk population (MARPs \& } \\
\text { ARPs) of HIV/AIDS before and after intervention }(n=121)\end{array}$} \\
\hline \multirow[t]{2}{*}{ MARPs \&ARPs } & \multicolumn{2}{|c|}{ Before educational intervention } & \multicolumn{2}{|c|}{ After educational intervention } \\
\hline & Number & Percent & Number & Percent \\
\hline Injecting drug users & 98 & 81.0 & 117 & 96.7 \\
\hline Female sex workers & 115 & 95.0 & 119 & 98.3 \\
\hline MSM & 21 & 17.4 & 106 & 87.6 \\
\hline Migrant workers & 102 & 84.3 & 120 & 99.2 \\
\hline Young people & 100 & 82.6 & 119 & 98.3 \\
\hline Women & 72 & 59.5 & 118 & 97.5 \\
\hline Uniform service & 62 & 51.2 & 103 & 85.1 \\
\hline Infant (mother to child) & 101 & 83.2 & 118 & 97.3 \\
\hline Refugee & 50 & 41.3 & 98 & 81.0 \\
\hline Prisoners & 23 & 19.0 & 103 & 85.1 \\
\hline
\end{tabular}


Table 6: Knowledge Regarding Source of Transmission of HIV/AID before and after intervention

\begin{tabular}{|l|c|c|c|c|}
\hline \multicolumn{1}{|c|}{$\begin{array}{c}\text { Sources of transmission of HIV/ } \\
\text { AIDS }\end{array}$} & \multicolumn{2}{c|}{$\begin{array}{c}\text { Before educational } \\
\text { intervention }\end{array}$} & \multicolumn{2}{c|}{$\begin{array}{c}\text { After educational } \\
\text { intervention }\end{array}$} \\
\hline & Number & Percent & Number & Percent \\
\hline Unprotected sexual contact & 115 & 95.0 & 120 & 99.2 \\
\hline Contaminated blood transfusion & 116 & 95.9 & 120 & 99.2 \\
\hline Organ/semen donation & 61 & 50.4 & 114 & 94.2 \\
\hline Sharing contaminated needle/syringe & 112 & 92.6 & 117 & 96.7 \\
\hline Contaminated blade razor & 104 & 86.0 & 117 & 96.7 \\
\hline HIV transmit to child during pregnant & 110 & 90.9 & 118 & 97.5 \\
\hline HIV transmit to child in breast feed & 57 & 47.1 & 111 & 91.7 \\
\hline HIV transmit to child in labour & 98 & 81.0 & 119 & 98.3 \\
\hline
\end{tabular}

Table 7: Knowledge Regarding Prevent HIV/AIDS Transmission before and after intervention

\begin{tabular}{|l|c|c|c|c|}
\hline Methods to prevent HIV/AIDs & \multicolumn{2}{|c}{$\begin{array}{c}\text { Before educational } \\
\text { intervention }\end{array}$} & \multicolumn{2}{c|}{$\begin{array}{c}\text { After educational } \\
\text { intervention }\end{array}$} \\
\hline & Number & Percent & Number & Percent \\
\hline Sex only with faithful & 103 & 85.1 & 118 & 97.5 \\
\hline Use screen blood or blood product & 90 & 74.4 & 108 & 89.3 \\
\hline Use sterile needle/syringe & 111 & 91.7 & 119 & 98.3 \\
\hline Use condom safer & 115 & 95.0 & 120 & 99.2 \\
\hline Not sharing blade/razor & 99 & 81.8 & 105 & 86.0 \\
\hline HIV infected mother take ARV & 13 & 10.7 & 102 & 84.3 \\
\hline Use sterile equipment & 111 & 91.7 & 114 & 94.2 \\
\hline
\end{tabular}

was seen in post test that this increased to 82 $\%$ with $\mathrm{P}$ value of 0.001 , this is a significant change.

There was also significant change in knowledge regarding contributing factors that has led to increasing prevalence of HIV/AIDS in Nepal. Before educational intervention 33.1 $\%$ to $95.9 \%$ of respondents were aware that girl trafficking, low level of condom use, low literacy level, cultural \& religious values, social stigma, discrimination and unemployment were the chief causes leading to rising prevalence of HIV/AIDS. After the education intervention it was raised to $76 \%$ to $100 \%$. Paudel B N et al. have reported that migrant laborers (38.8\%) and illeterates (77\%) form the major chunk of people infected by HIV/AIDS ${ }^{5}$. Similarly $12.9 \%$ of people infected by HIV/AIDS had only primary level 
Table 8: Knowledge Regarding Prevention of Mother to Child transmission (PMTCT) of HIV before and after intervention $(n=121)$

PMITCT of HIV Before educational intervention After educational intervention

\begin{tabular}{|l|c|c|c|c|}
\hline & Number & Percent & Number & Percent \\
\hline $\begin{array}{l}\text { Take ARV during } \\
\text { pregnancy }\end{array}$ & 48 & 39.7 & 110 & 90.9 \\
\hline Take ARV during labour & 30 & 24.8 & 98 & 81.0 \\
\hline Perform caesarean section & 21 & 17.4 & 62 & 51.2 \\
\hline Avoid breast feeding & 31 & 25.6 & 77 & 63.6 \\
\hline $\begin{array}{l}\text { Start ARV treatment to } \\
\text { infant }\end{array}$ & 30 & 24.8 & 90 & 74.4 \\
\hline
\end{tabular}

Table 9: Comparison of level of knowledge regarding prevention of HIV/AIDS, $\mathrm{P}=0.000$

\begin{tabular}{|l|c|c|c|c|}
\hline Level of knowledge & \multicolumn{2}{|c|}{ Before educational intervention } & \multicolumn{2}{|c|}{ After educational intervention } \\
\hline & Number & Percent & Number & Percent \\
\hline Low $(<60 \%)$ & 58 & 47.9 & 1 & 0.8 \\
\hline High $(60-80 \%$ above $)$ & 63 & 52.0 & 120 & 99.2 \\
\hline Total & 121 & 100 & 121 & 100 \\
\hline
\end{tabular}

of education ${ }^{5}$. The responses from the subjects of our study was coherent with Paudel's study.

Most at risk \& at risk population (MARPs \& ARPs) of HIV/AIDS to be young people, women, gay, prisoner, refugee, migrant workers, uniformed service, infant (mother to child), female sex worker and injecting drug users were correctly identified by $17.4 \%$ to $95.0 \%$ of respondents before intervention. The level of knowledge regarding MARPS and ARPs increased to $81.0 \%$ to $99.2 \%$ after intervention. Such knowledge about MARPs and ARPs among general population will help focus the emphasis on prevention programs of HIV/AIDS ${ }^{6}$.

One study done in adolescents of Bangladesh showed that $96.1 \%$ of them had knowledge about transmission of HIV by sexual contact, $92.3 \%$ knew about mother to fetus transmission and and $72.0 \%$ of them thought that HIV is also transmitted by breast milk ${ }^{7}$.

After educational intervention, $99 \%$ respondents had knowledge that HIV/AIDS get transmitted through unprotected sexual contact. Before the course $47.1 \%$ to $90.9 \%$ participants responded that HIV can be transmitted from mother to child during pregnancy, during labour and breast feeding; after the course this raised to $91.7 \%$ t to 98.3 $\%$. Similarly, before the intervention only $39.7 \%$ and $24.8 \%$ participants were aware that taking ARV regularly during pregnancy and during labour reduces the chances of HIV transmission from mother to child. The level of knowledge was raised to $90.9 \%$ and $81.0 \%$ respectively after interventions.

\section{CONCLUSION}


It can be concluded that educational intervention has role to increase awareness about HIV/AIDS.

\section{REFERENCES}

1. Joint United Nations Program on HIV/ Aids (UNAIDS). UNAIDS WORLD AIDS DAY REPORT 2011. (http://www.unaids.org/ sites/default/files/media_asset/

JC2216_WorldAIDSday_report_2011_en_0. pdf)

2. Diclement R J, Durbin MD, Siegel F, Kransnovsky N, Lazarus T O; Determinants of condom use among Junior high school students in a minority inter-city school Disok pediatric. 1992; 2:197-202. (http:// www.ncbi.nlm.nih.gov/pubmed/1734383)

3. Ministry of Health and Population Department of Health Services Annual report Kathmandu, Nepal; 2066/67. (dohs.gov.np/wp-content/uploads/2014/04/ Annual_Report_2066_67.pdf)

4. Sharma M. Impact of education intervention on knowledge regarding HIV/AIDS among adult. J Nepal health council. 2008;6:102-106.

5. Paudel BN, Sharma S, Singh GB, Dhungana GP, Paudel P. Socio-Demographic Profile of HIV patients at Seti Zonal Hospital. J Nepal Health Research Council. 2008; 2: 107-110. (www.nepjol.info/index.php/JNHRC/article/ download/2215/2037)

6. Ministry of Health \& Population, Nepal Demographic and Health Survey ; 2011; 189-214. (un.org.np/data-coll/HealthPublications/2011_NDHS.pdf)

7. Uddin $\mathrm{M} A$, Isaramalai $\mathrm{S}$, Thassari $\mathrm{J}$; Knowledge and attitude regarding HIV/ AIDS prevention among Adolescent in Bangladesh. The $2^{\text {nd }}$ international Conference on humanities and Social
Science. J Faculty of Arts Prince of Songkla University.2010; .1-12.

8. Yerdaw M, Nedi T, Enquoeslassie F; Assessment of awareness of HIV/AIDS among selected target group in around Addis Ababa, Ethiopia. African $\mathrm{J}$ of Reproductive Health. 2002; 6:(2):30-38

9. Adegbola O, Babalola J O; Sexual networking in Freetown the background of AIDS epidemics. Health Transtion Review. 1995; 5: 81-110. (m.scirp.org/papers/49327)

10. Briwn L, Trujillo L, Macintyre Intervention to reduce HIV/AIDS stigma; what have we learned? PopulationCouncillnc.2001.(http:// brownschool.wustl.edu/sites/DevPractice/ HIVAIDS\%20Reports/Interventions\%20to $\% 20$ Reduce $\% 20$ HIV\%20and\%20AIDS $\%$ 20Stigma.pdf.)

11. Ebeniro C D; Knowledge and beliefs about HIV/AIDS among male and female students of Nigerian University. $J$ comparative Research in Anthropology and Sociology. 2010 ;. 1: (1 ) 121-131. (http:// doctorat.sas.unibuc.ro/wpcontent/uploads/ 2010/10ChiomaEbeniro_Compaso2010.pdf. )

12. Fantahun M, Chala F E; Sexual behavior, and knowledge and attitude towards HIV/ AIDS among out of school out in Bahir Dar Town, Northwest Ethiopia. J Ethiop Med. 1996; 3 4:2 33 (dare.uva.nl/document/ 78073)

13. Gao X, Wu Y, Zhang Y, Zhang N, Tang J; Effectiveness of School-based Education on HIV/AIDS Knowledge, Attitude, and Behavior among Secondary School Students in Wuhan.J Chin.2012;7:9. (journals.plos.org/plosone/article? $\mathrm{id}=10.1371$ journal.pone.0044881) 
14. Herbst J, Sherba R, Crepaz N; A Metaanalytic Review of HIV Behavioral Intervention for reducing sexual Risk Behavior of Men who have Sex with Men. J .2005; 39:228-241.( www.ncbi.nlm.nih.gov/ pubmed/15905741)

15. Odu K B, Akanle F F; Knowledge of HIV/ AIDS and Sexual behavior among the Youths in Southwest Nigeria. J Humanity \& Social Sciences.2008;1:81-88. (citeseerx.ist.psu.edu/viewdoc/download? doi $=10.1 .1 .525 .8648 \&$ rep=rep1...pdf)
16. Subedi P D, Bhattari, G.S. Midwifery nursing: Baneshor, Kathmandu, Medhavi Poblication,2010.

17. Taher E, Abdelhai R; Nurse knowledge perception and attitude towards HIV/AIDS: Effect of a health education intervention on two nursing groups in Cairo University, Egypt. J public Health and Epidemiology. 2011; 4: 144-145.

18. Selected target Group in around Addis Alban, Ethiopia. J African of reproductive health. 2002;2:. 